\title{
Simple Endometrial Hyperplasia without Atypia
}

National Cancer Institute

\section{Source}

National Cancer Institute. Simple Endometrial Hyperplasia without Atypia. NCI Thesaurus.

Code C6992.

A proliferation of endometrial cells resulting in glandular enlargement and budding without changes in the basic structure of the endometrium. Epithelial atypia is absent. 